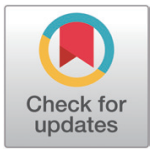

Received: Dec 22, 2020

Revised: Feb 4, 2021

Accepted: Feb 8, 2021

*Corresponding author

Sunjin Hur

Department of Animal Science and

Technology, Chung-Ang University,

Anseong 17546, Korea.

Tel: +82-31-670-4673

E-mail: hursj@cau.ac.kr

Sungkwon Park

Department of Food Science and

Biotechnology, Sejong Univeristy, Seoul

05006, Korea.

Tel: +82-2-3408-2906

E-mail: sungkwonpark@sejong.ac.kr

Copyright $\odot 2021$ Korean Society of

Animal Sciences and Technology.

This is an Open Access article

distributed under the terms of the

Creative Commons Attribution

Non-Commercial License (http://

creativecommons.org/licenses/by-

$\mathrm{nc} / 4.0 /$ ) which permits unrestricted

non-commercial use, distribution, and

reproduction in any medium, provided

the original work is properly cited.

ORCID

Sivasubramanian Ramani

https://orcid.org/0000-0001-9370-6552

Deunsol Ko

https://orcid.org/0000-0002-7084-3551

Bosung Kim

https://orcid.org/0000-0002-5417-0238

Changjun Cho

https://orcid.org/0000-0001-7964-3452

Woosang Kim

https://orcid.org/0000-0003-3742-5603

Cheorun Jo

https://orcid.org/0000-0003-2109-3798

\section{Technical requirements for cultured meat production: a review}

\author{
Sivasubramanian Ramani ${ }^{1}$, Deunsol $\mathrm{Ko}^{1}$, Bosung $\mathrm{Kim}^{1}$, Changjun $\mathrm{Cho}^{1}$, \\ Woosang Kim ${ }^{1}$, Cheorun $\mathrm{Jo}^{2}$, Chang-Kyu Lee ${ }^{2}$, Jungsun $\mathrm{Kang}^{3}$, Sunjin Hur ${ }^{4 *}$ \\ and Sungkwon Park ${ }^{1 *}$
}

${ }^{1}$ Department of Food Science and Biotechnology, Sejong University, Seoul 05006, Korea

${ }^{2}$ Department of Agricultural Biotechnology, Center for Food and Bioconvergence, and Research Institute of Agriculture and Life Sciences, Seoul National University, Seoul 08826, Korea

${ }^{3}$ Genebiotech, Seoul 06774, Korea

${ }^{4}$ Department of Animal Science and Technology, Chung-Ang University, Anseong 17546, Korea

\section{Abstract}

Environment, food, and disease have a selective force on the present and future as well as our genome. Adaptation of livestock and the environmental nexus, including forest encroachment for anthropological needs, has been proven to cause emerging infectious diseases. Further, these demand changes in meat production and market systems. Meat is a reliable source of protein, with a majority of the world population consumes meat. To meet the increasing demands of meat production as well as address issues, such as current environmental pollution, animal welfare, and outbreaks, cellular agriculture has emerged as one of the next industrial revolutions. Lab grown meat or cell cultured meat is a promising way to pursue this; however, it still needs to resemble traditional meat and be assured safety for human consumption. Further, to mimic the palatability of traditional meat, the process of cultured meat production starts from skeletal muscle progenitor cells isolated from animals that proliferate and differentiate into skeletal muscle using cell culture techniques. Due to several lacunae in the current approaches, production of muscle replicas is not possible yet. Our review shows that constant research in this field will resolve the existing constraints and enable successful cultured meat production in the near future. Therefore, production of cultured meat is a better solution that looks after environmental issues, spread of outbreaks, antibiotic resistance through the zoonotic spread, food and economic crises.

Keywords: Cultured meat, Meat alternative, Next industrial revolution, Livestock and environment axis, Health and wellness, Emerging infectious disease

\section{NEED FOR AN ALTERNATIVE SOURCE OF MEAT}

\section{Livestock are a potential source of emerging pandemics}

Historians and evolutionary biologists now comprehend infectious diseases as the forces that selectively decide our future and genome. Dietary patterns of domesticated animals along with the environment drives the emergence of such infectious diseases. Proximity and interactions between humans and the animal populations are the major underlying causes of this phenomenon [1]. The recently emerged and ongoing COVID-19 pandemic is one such example, which is assumed to have originated in Wuhan, 
Chang-Kyu Lee

https://orcid.org/0000-0001-6341-0013

Jungsun Kang

https://orcid.org/0000-0001-9072-8211

Sunjin Hur

https://orcid.org/0000-0001-9386-5852

Sungkwon Park

https://orcid.org/0000-0002-7684-9719

Competing interests

No potential conflict of interest relevant to this article was reported.

Funding sources

This work was supported by Sejong University; Korea Institute of Planning and Evaluation for Technology in Food, Agriculture and Forestry (iPET) through Development of High Value-Added Food Technology Program funded by the Ministry of Agriculture, Food and Rural Affairs (MAFRA; 118042-03-3-HD020); and the Technology Innovation Program (20012411, Alchemist Project) funded by the Ministry of Trade, Industry and Energy (MOTIE).

Acknowledgements

Not applicable.

Availability of data and material Upon reasonable request, the datasets of this study can be available from the corresponding author.

\section{Authors' contributions}

Conceptualization: Ramani S, Park S.

Data curation: Ramani S, Ko D, Kim B, Cho C, Kim W.

Formal analysis: Ramani S, Ko D, Kim B, Cho C, Kim W.

Software: Ramani S, Park S.

Validation: Jo C, Lee CK, Kang J.

Investigation: Ramani S, Park S.

Writing - original draft: Ramani S, Park S.

Writing - review \& editing: Ramani S, Hur S Park S.

Ethics approval and consent to participate This article does not require IRB/IACUC approval because there are no human and animal participants.
China [2,3]. Origin of this virus is possibly via a zoonotic transfer from forest-based reservoir animals to humans $[4,5]$. Zoonotic diseases are prone to emerge and re-emerge, whereby their incidence and frequency are intricately linked and based on the agricultural-environmental nexus. Further, a similar study has provided molecular evidence of zooanthroponosis, the transmission of disease from humans to animals [6,7].

On a global scale, emerging infectious diseases (EIDs) and growing hotspots are based on demographic, environmental, and biological factors (Fig. 1). Interestingly, these two aspects have been reported to be correlated with the rise of zoonotic EIDs, whereby forest encroachments enhance/elevate this risk. [8]. There has been a significant increase in the occurrence of EIDs. Reportedly, around 73\% of them (roughly accounts to 335 EID events occurred between 1940 and 2004) are zoonotic origin [6,9]. Livestock not only contributes majorly to global warming but it also plays adverse roles in zoonotic EIDs. Maintaining health, performance, and production of livestock has turned out to be exceedingly difficult. Although constant searches for better animal feeding system to improve healthiness and productivity of livestock animal are in progress, no significant advancements suitable for existing or future populations have been discovered yet. In general, feed supplements, such as subclinical dosage of antimicrobials, plant extracts, probiotics, prebiotics, or a combination of them control livestock infections [10-14]. Although such measures are taken, EIDs and food-borne outbreaks, global warming, huge land usage, and forest encroachments are still on the rise and inevitable.

\section{Meat as preferred protein source}

Meat is a reliable source of protein and energy. A majority of the world population constitute meat-eaters. Evolution and social interactions are the major reasons that have accounted for our carnivorous nature. Our ancestors moved from the hunter-scavenger lifestyle to animal farming by domesticating wild animals as a custom that ensured food security. However, such practices have become a threat to the planet's biotic and abiotic resources in the contemporary times $[15,16]$

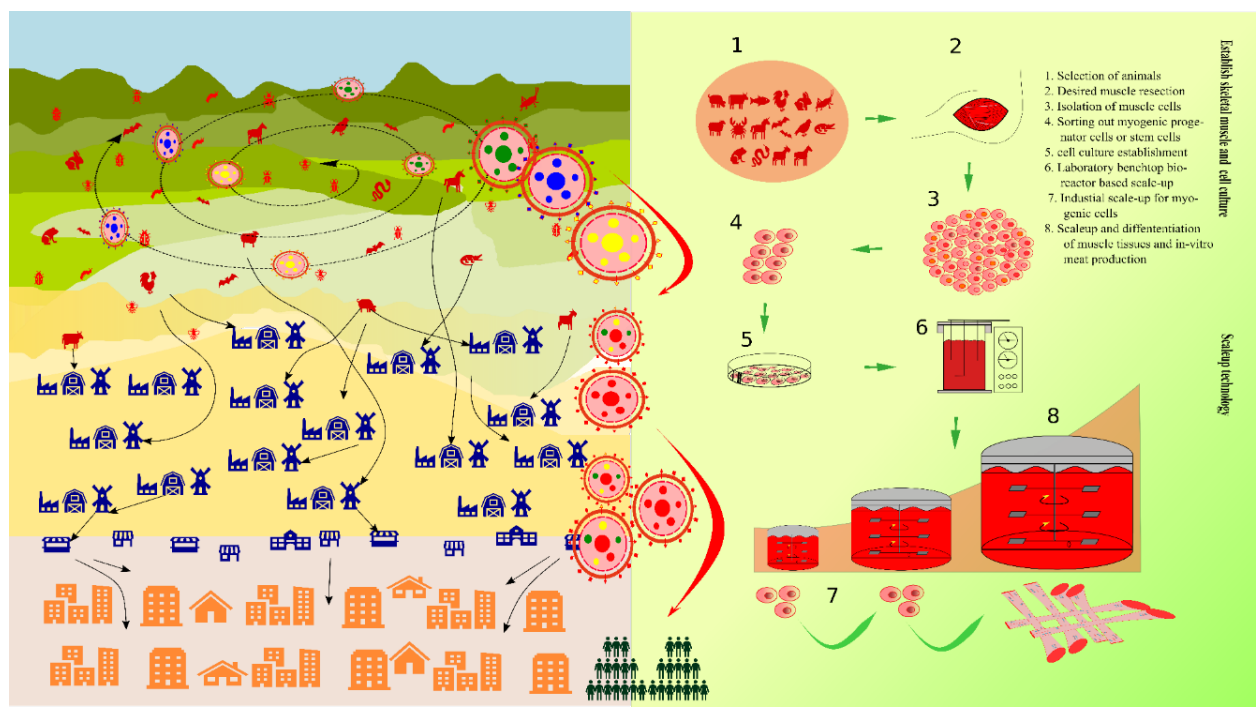

Fig. 1. Emerging infectious deseases (EIDs), environment, and cultured meat production. (A) Flow of EID as the forest encroached for human food consumption. Forest is the reservoir of the novel infectious agents the infectious agents are naturally genetic recombined when cross infected between animal to animal, the flow is redirected when there is any human interference where the cycle changes from animal to human host by same genetic recombination and adaptation leading to zoonosis (ex, COVID19, anthrax, swine flu, etc.). (B) Overview of cultured meat establishment and scale-up for such drivers is anthropogenic. Such anthropogenic utilities are forest encroachment, land-use changes, livestock intensification, etc. [6,64] 
It is estimated that by 2100 the world population would increase by at least $9.6-12.3$ billion, a number that is enormous as compared to the current scenario [17]. Furthermore, malnutrition is currently a significant problem worldwide. To overcome global hunger and undernutrition, the overall push towards food security has improved sustainable food production. Although food production has improved qualitatively and quantitatively, global availability of resources often leads to various environmental, food-related, and health issues [18-20]. It is quite evident that anthropological meat-eating affects climate change to a great extent. However, the global population cannot be forced to abandon meat consumption. Thus, novel technology-based innovations that can help overcome such issues by developing alternative forms of meat which can be multivalued based on health and environmental factors are of utmost importance.

Substantial advancements in livestock can be witnessed since the commencement of the industrial revolution. The future of livestock relies on the present technological revolution, now possible with the state of the art technologies in robotics and sensing toolkits [21]. Food engineering has unlocked many such solutions till date, an alternative to animal meat being one of them. With the advent of breakthrough milestones in stem cell technology (Fig. 2), it is now possible to direct stem cells towards highly differentiated cells, for instance, satellite cells (SCs) can be directed towards skeletal muscle cells in many animals [22,23]. A single cell can be used to produce massive quantities of skeletal muscle cells by way of stem cell technology which is better known as in vitro meat (IVM), in vitro meat agriculture (IMA), or cultured meat; this innovation is a promising alternative to livestock. In a news feature in October 2009, Jeffrey L. Fox highlighted IMA's potential to be served as a "test tube made of meat" by 2022 [24]. In August 2017, Amber Dance featured IMA approach as an option to meat and other animal-derived products, such as milk, eggs, and even leather. Therefore, IMA is a promising alternative to meat, whereby it is a multifaceted solution for food, health, and environmental issues [25]. The fact that IMAderived products can be customized according to one's needs is advantageous over conventional animal farming. In contrast, customization of livestock animals, such as genetic modifications, feed modifications, usage of antibiotics and synthetic hormones, etc., which are carried out for the sake of better animal performance, marbling scores, and carcass weight, often can create hurdles.

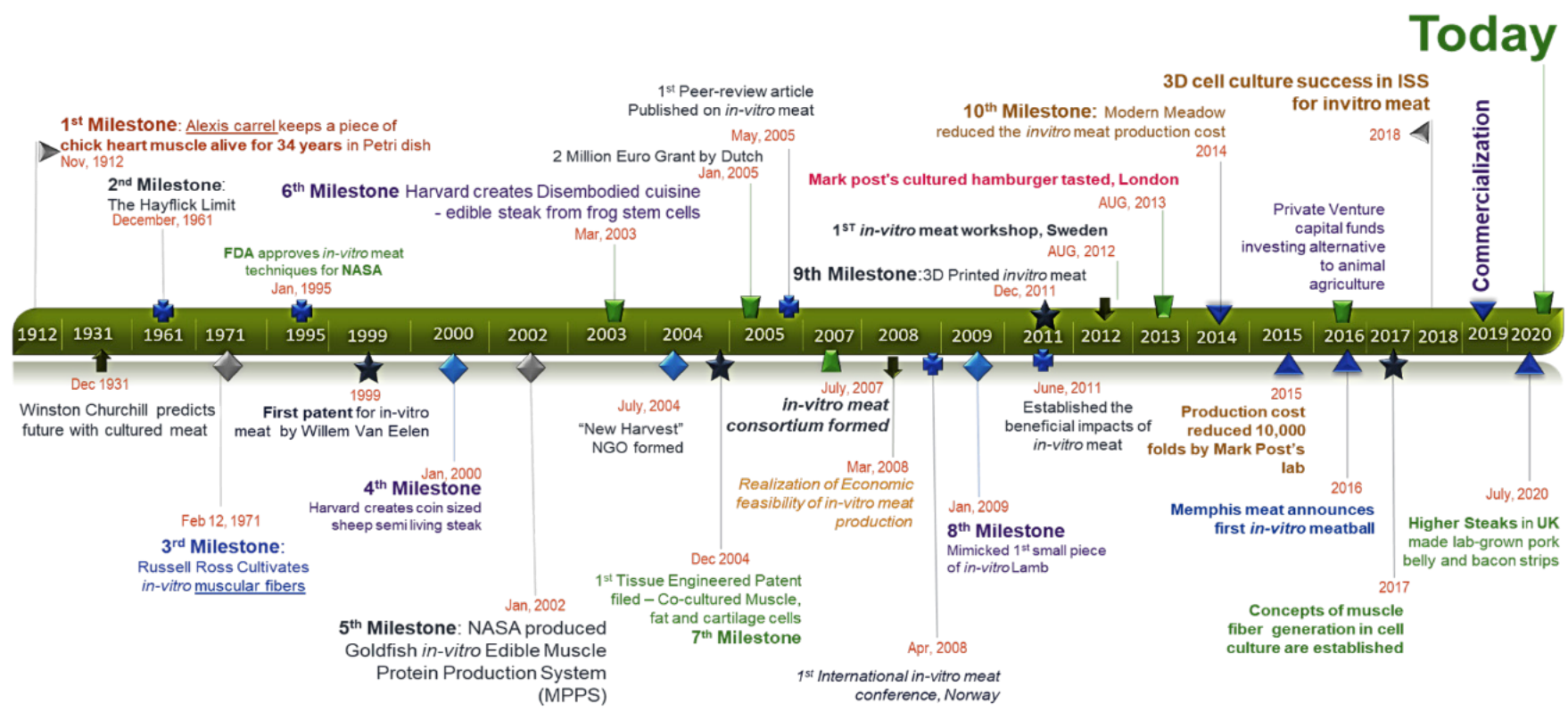

Fig. 2. Timeline of in vitro meat from start of cell culture to culture meat production. 
Although IMA is in its infancy stage at present, future possibilities that lie ahead are larger than expected, as witnessed in case of other technological innovations. Bovine cultured meat was commercially produced first in 2013. Since then, many startups have risen producing a variety of animal culture meat and products. At least 35 such startups worldwide have exponentially produced poultry, bovine, pork, and marine animals, including salmon, other fish, shrimps, since 2013, covering $85 \%$ of the total cultured meat market size. On the other hand, horse, kangaroo, mouse, and other animal types cover share of this market [26].

\section{Need for revision of regulations for cultured meat production}

Although IVM is gaining enough attention, its production has not been streamlined. To date, startups follow the necessary measures for IMA and the cultured meat is considered safe. However, no government has assembled regulatory bodies that completely assesses the safety parameters required for producing IMA. Cultured meat production is bound to face investment crises in the absence of such regulatory bodies. Thereby, the industries expected governments to set up regulatory guidelines for large-scale production. Between July and October 2018, the Departments of Health and Human Services announced in public meetings the joint development of a regulatory framework for cell-cultured meat production, including hazards and labeling. Services of the U.S. Food and Drug Administration (FDA) and U.S. Department of Agriculture (USDA) Food Safety and Inspection Service (FSIS) hazard analysis and critical control point (HACCP) are well documented. In case of cell-cultured meat, both the agencies will work together; FDA's risk base approach coupled with FSIS's regular inspection oversight approach are considered to mitigate contamination problems during cell culture or cell-cultured meat production [27].

Both the FDA and USDA have assured that this regulatory framework can be successfully implemented and guarantees safety. These agencies have undertaken the responsibility to monitor initial stages of cell culture and their multi-stage governance has agreed to regulate the production and labeling of cell-cultured meat [28,29]. On March 7, 2019, USDA-FSIS and health and human services (HHS)-FDA jointly announced the formal agreement that addresses the joint regulatory frame for cell-culture meat production. The agreement includes inspecting and overseeing human food produced by cell culture, derived from cell lines of USDA-amenable species [30].

There lacks an appropriate direction that allows choice of cells for cell-cultured meat production, as of now. The underlying technology and strategy rely on stem cells or precursor cells, which are of many types. In addition, right from proliferation to differentiation of the skeletal muscle cells, various culture conditions and materials, including the use of animal-based serum, encounter many ethical and technical issues. Thus, the scientific, ethical, and legislative issues that span collection of tissue samples up to mass cultivation must be crucially considered and successfully resolved.

Moreover, use of genetically modified organisms (GMOs) or engineered products, such as growth promoters and serum alternatives, in cell culturing or cell-cultured meat production is a great challenge. The harvested cells should be free of any microbial contamination, including bacteria, fungi, and viruses. Contamination by other genetic materials, such as drug-resistant plasmids, should be monitored as well. Further, presence/use of toxic substances, allergens, and any adulterants should be avoided. Moreover, biomass produced from microorganisms, such as microalgae, is the alternative potential source of cell culture media [31]. Recent amendments of the regulatory system by the EU (European Union) and US-based aforementioned bodies are expected to accelerate this technology in the forward direction in both research and industry. However, the current regulations are primitive; thus, only minimal extent to mitigate the hazards and future risks are possible as of now. Additionally, regulatory bodies must periodically update these guidelines to prevent any unexpected hazards effectively. 


\section{REQUIREMENTS FOR PRODUCTION OF CELL-CULTURED MEAT}

\section{Stem cells}

In 1961, Alexander Mauro for the first time reported SCs, wherein he assumed them to be related with muscle fiber regeneration [32]. Today, this is an established concept and is a key component for the future IMA revolution. Molecular regulations involved in culturing of embryonic stem cells and skeletal muscle cells has been well established and reviewed previously [33]. Briefly, during the course of muscle development an animal requires coordinated events, namely regulated myogenic signaling cascade followed by proliferation, differentiation, and maturation of the progenitor cells, to form skeletal muscle cells. Anatomically, these stem cells reside beneath the basal lamina surrounding the myofibers; they are self-renewal and function as the source of regeneration [34]. SCs express paired box transcription factors paried box (Pax) 3 and Pax7, along with basic helixloop-helix factors myoblast determination protein (MyoD), myogenic factor (Myf) 5, Myf6, and myogenin (often termed as the myogenic regulatory factors, MRFs). These transcription factors can be observed in cluster of differentiation (CD) $56^{+} \mathrm{CD} 29^{+} \mathrm{CD} 31^{-} \mathrm{CD} 45^{-}$cell population; they are highly conserved and have been recently characterized in porcine cells $[35,36]$. Apart from SCs, another suitable progenitor candidate is PW1+ interstitial cell (PIC). Although they express Pax3 and Pax7 similar to SCs, PICs are more plastic with the expression of octamer-binding transcription factor (Oct) 3/4, sex determining region Y (SRY)-box transcription factor (Sox) 2, and Nanog. Moreover, SCs are only confined to skeletal muscle cell differentiation, whereas PICs can differentiate to skeletal as well as smooth muscle cells and adipocytes. In addition, differential gene expression analysis revealed that SCs express only the myogenic commitment gene sets, while PICs are also related to mesenchymal stem cell markers, indicating their multipotent nature. Certainly, stem cells antigen (sca)-1 marker can be utilized to identify PICs' isolation at certain time point during development, since this marker is present only in the first three weeks of postnatal age, but it disappears later [37-40]. Other molecular regulators of proliferation and differentiation include microRNA(miR)-1, miR-206, and miR-133.

Many model approaches have been used for the mass cultivation of animal meat. With the passage of time and corresponding technological advancements, various methods have progressed in this regard. Although cell-cultured meat has garnered much attention, its production continues to face economic and technical challenges. The cultivation methods include 2 dimension (2D) and 3D culturing models, which have been discussed previously [41]. The following section briefly summarizes these models.

\section{Scaffolds and microbeads}

2D models where cells can be cultured in Petri dishes or cell culture factories. Although the 2D model has limitations with respect to mass cultivation, it serves as an efficient and beneficial model at laboratory research for small-scale optimization. On the other hand, 3D models provide an array of options; they are comparatively less limited as compared to the 2D models for cultivation. However, it is exceedingly difficult to optimize the cultivation condition, which is still at the preliminary research stage and would require more efforts and time before it reaches large-scale production $[35,42,43]$

The 3D models (Table 1) include gel-based and scaffold-based approaches. In case of an in-gel system, a variety of biomolecules, such as collagen, fibrin, etc., can be embedded. Moreover, these gel systems can contain uniformly distributed cells, rendering efficient mimicking of the natural tissue mechanical responses production $[35,42,43]$. In the scaffold-based approach, biopolymer 
Table 1. Summary of current status of technical issues and future required improvements for IMA

\begin{tabular}{|c|c|c|c|}
\hline S.No. & $\begin{array}{l}\text { Technical } \\
\text { requirements }\end{array}$ & Current status & Required approaches \\
\hline 1 & Cell bank & $\begin{array}{l}\text { Except for Homo sapiens other primary cells } \\
\text { are not reposited. No other primary muscle or } \\
\text { adipose cell line is submitted. }\end{array}$ & $\begin{array}{l}\text { Currently research for production is carried for bovine, porcine, chicken, fish, } \\
\text { shrimps, horse, duck, kangaroo, rats. Central cell bank should be created and } \\
\text { maintained for all the culture meat cell lines will be carried for research and } \\
\text { production. }\end{array}$ \\
\hline 2 & Database & $\begin{array}{l}\text { No reference database is available except } \\
\text { published research articles }\end{array}$ & $\begin{array}{l}\text { Reference range for every IMA muscle models, Muscle cells, Adipose cells, } \\
\text { Specifications for Proliferation, Differentiation, Required Biomaterials, Culture } \\
\text { conditions, 2D and } 3 \mathrm{D} \text { culture requirements, material requirements, Contam- } \\
\text { inants including chemicals, physical and biological, Texture, taste, Nutritional } \\
\text { value, Source of animals, genetic information and regulatory systems. }\end{array}$ \\
\hline 3 & Culturing media & $\begin{array}{l}\text { 1) Currently used media are generalized } \\
\text { media which suits every cell type but not } \\
\text { specifically for muscle cells. } \\
\text { 2) No specific medium for proliferation or } \\
\text { differentiation is available for different type } \\
\text { of animal muscle or adipose. } \\
\text { 3) High cost }\end{array}$ & $\begin{array}{l}\text { 1) Animal type and cell type specific culture media should be engineered under- } \\
\text { standing the requirements based on genetic predisposition. } \\
\text { 2) Both proliferation and differentiation are different state of cell existence this } \\
\text { the nutrition requirements, thus based on the cell metabolism and gene } \\
\text { expression profile the required nutrition composition has to be formulated. } \\
\text { 3) Instead of animal source and plant source, using cloning technologies for } \\
\text { growth factors or othr protein components for large scale will help in cost } \\
\text { reduction. } \\
\text { 4) Co-culture supporting medium. }\end{array}$ \\
\hline 4 & $\begin{array}{l}\text { Scaffold \& Micro- } \\
\text { carriers for 3D } \\
\text { culture }\end{array}$ & $\begin{array}{l}\text { 1) Non-edible scaffolds or microcarriers are } \\
\text { synthesized with edible materials due to } \\
\text { the production methods. } \\
\text { 2) High cost for material and production. } \\
\text { 3) Labor intensive and still at research scale } \\
\text { thus not readily available. }\end{array}$ & $\begin{array}{l}\text { 1) Edible and digestible scaffolds or microcarriers should be produced with food } \\
\text { grade materials and methods. } \\
\text { 2) Produced materials should mimic the tissue or meat rheological properties. } \\
\text { 3) Stability of materials (temperature, sheer stress, shelf life). } \\
\text { 4) Animal-free materials are recommended. } \\
\text { 5) Nutrition and oxygen perfusion should be perfected. } \\
\text { 6) Mimic systemic vascularization. } \\
\text { 7) Water holding capacity. } \\
\text { 8) Less cooking loss. }\end{array}$ \\
\hline
\end{tabular}

5 Regulatory No complete guidelines or regulations are framed for productions or for IMA research.

6 Proliferation and Primely based on the serum. concentration differentiation and very few factors like Insulin, EGF, transferrin, selenium, p38, etc., supplements.

Complete guidelines and regulatory documentation should be made as to every aspect for raw materials, cell lines or bank, productions methods, media usage, etc.

1) Specific hub proteins to direct a progenitor or stem cell towards proliferative or differentiation state.

2) Methods to direct the biochemical pathways for higher production.

3) Inducers to fasten the cell cycle to change from progenitor state to proliferative state and differentiation state.

This process is critical to control the cost and production issues.

7 Serum

1) Batch to batch variation

2) Supply and demand

3) Ethical and animal welfare

8 Anti-microbials High proportions of anti-bacterial, anti-fungal and Antibiotics which are in general clinical use, as increased use of antibiotics will create drug resistance for clinical settings, inflated cost, cell stress.

9 Bioreactors
1) Operational cost
2) Sheer stress
3) Nutrition diffusion
4) Scalability
5) Viability
6) Quality
7) labor intensive
8) Contamination
9) Optimization
10) Storage
11) Mobilization

1) Nutrition defined serum free medium for different cell state.

2) Alternative to serum from non-animal source.

3) Synthetic serum rather than animal source.

Alternatives to antibiotics for example anti-microbial peptides, lysins, bacteriocins, SMAMP's, IDR peptides, biological extracts, which will not be a stress factor or create drug resistance.

Bioreactors issues are complex and bottle necks with various factors. Every stage should be carefully monitored and optimized. Any issue in the reactor leads to huge economic issues. Thus, every stage must be optimized for betterment and production of cells.

utilization is the alternative. Various scaffolds are available that can be used for requirement-based customization. Scaffolds are highly customizable with respect to mechanical stiffness, degradation upon vasculature, flexible architecture, and in vivo mimicking [41]. Apart from the animal origin biomaterials alternatively plant, microbial origin or synthetic edible food grade polymers should be considered for the scaffolds and microbead synthesis. One of the major issues in producing scaffolds are the synthesis methodology involves various harsh chemicals which makes the end product as non-edible scaffolds though the initial raw materials are edible grade. Few plants based promising biopolymers are polysaccharides like amylose and its derivatives, polyesters, alginates, chitin, 
hyaluronic acids etc. In case of scaffold based 3D culture perfusion of nutrition is also one of the major issues, apart from that accessibility for the cells to migrate inside the matrix is also difficult if the porous space is too small. Considering both the factors together in scaffold-based technology both nutrition perfusion and increased porous with high degree of matrix will enhance the cell growth which will avoid the cell growth only on the surface. Notably, these methods are called tissue engineering techniques. Further, availability of recent advancements including 3D printing has elevated these approaches. Recently, 3D bioprinting of the human skeletal muscle cells and tissues restored muscle function [44]. The final product from the scaffold should be able to hold the water upon cooking and integrity of the structure also plays a key role, hence the material's stability also influence the texture and palatability, so the market value. On the other hand, microbeadsbased cultivation has so far progressively up-scaled cell production, owing to their relatively larger surface area [45]. However, this technique can only increase the cell number, which is its major limitation [46]. Further, cell-based whole meat production is not yet possible, which requires further processing that can reproduce proper texture, appearance, taste, and flavor like meat from animal. In summary, the aforementioned culturing methods have various advantages and are highly popular in the present times owing to their feasibility and success rates. Even though such advance technologies exist, the question of scaling up cell-cultured meat production to an industrial level still exists.

In 1917, Warren H. Lewis and Margaret R. Lewis first described muscle formation [47] and the terms myotubes and myofiber were coined by Jorge Francisco Tello in the same year [48]. However, no sustained control over the cell types and their final fates has been reported to date. This gap can be filled by a combination of biophysical and biochemical elements that render controlled methods in IMA [49].

\section{Proliferation and differentiation}

Skeletal muscle cells are the basic units of myotubes and myofibers. Differentiating progenitor cells exhibit limited mitotic proliferation prior to myotube formation, but subsequently, exhibit no nuclear proliferation. Skeletal muscle cell cultures involve two phases, namely proliferation and differentiation. Proliferation of progenitor cells determines the quantity of cultured meat production, whereby higher rate of expansion of cells is achieved by increasing the efficiency of cell doublings. Differentiation is an important phase to achieve the required characteristics for IVM. Moreover, as mentioned before, controlling SC population in its progenitor state is crucial, wherein many factors are involved to maintain the stem cell or progenitor state [50].

In case of IMA culture methods, extrinsic regulators should be chosen to avoid GMO issue. Extrinsic regulators involved in myogenesis that have been hardly trialed and optimized till date, should be considered for mass culture methods such that further progress in the field of IMA is met. A decade ago, there was no proper evidence to be considered for controlling IVM culture in a controlled manner. One such paradigm is fibronectin, an essential and adequate factor for wingless-type protein (Wnt) 7a signaling through frizzled class receptor (FZD) 7/stearoyl-CoA desaturase (Scd) 4 that can regulate the number of SCs [33]. In addition, $\mathrm{SC}$ status is regulated by metabolic activity, for instance reduced nicotinamide adenine dinucleotide (NAD)(+)-silent mating type information regulation 2 homolog (SIRT) 1 activity retains its progenitor property, by way of metabolic control of H4K16 acetylation. Strategic metabolic control over NAD(+)-SIRT1 activity can help in sustained retention of the SC status [51]. Other extrinsic factors that regulate SC status via facilitating proliferation but antagonizing differentiation are collagen $\mathrm{IV}$, transforming growth factor (TGF), insulin-like growth factor (IGF), Hepatocyte growth factor (HGF), basic fibroblast growth factor (bFGF), brain-derived neurotrophic factor (BDNF), epidermal growth factor (EGF), 
Tumor necrosis factor-like weak inducer of apoptosis (TWEAK), and Delta-1 [42,43,52]. In differentiation and myofiber formation, soluble extracellular domain of collagen XXV and alpha 6 integrin are cleaved, which is sufficient to promote formation of multinucleated myofibers [53,54].

\section{Culture media}

Culture medium is a key factor of any cell culture-based technology, including IVM production. The media preference for both proliferation and differentiation is variable and largely dependent on media composition as well as its cost. Therefore, culture media constitutes a major portion of the economic and technical issues associated with IMA currently. Till now there is no specific media based on the cell status or condition. Currently the media utilized is only a generalized medium which supports the growth for broad range of cells. In IMA, the isolated cells would be stem cells which will be further proliferated to specific progenitor cells and upon which is induced to differentiate into skeletal muscle cells. Hence, though everything are same cells but the cell's state is different, so the requirements of the cells also changes. Thus, there is need to formulate new medium for every particular metabolic state. This formulation may help in faster completion of the cell cycle hence a faster production can be achieved. Although most of the currently using media components required for proliferation and differentiation are similar, portions such as growth factors and molecules that stimulate differentiation are crucial for the latter phase. One such supplement is fetal bovine serum (FBS) that is widely used in cell culture owing to its non-activated immune system and absence of potential cytotoxicity. FBS is a rich source of growth factors and thus promotes cell growth; it also exhibits potential buffering capacity. Although FBS is beneficial in cell culturing techniques, there are limitations associated as well. These include batch to batch variability, ethical issues, and high cost due to extensive demand. Alternatively, FBS can be replaced by cloned growth factors, single cell proteins, or serum equivalent extracts of microbial-origin to cut down the production cost substantially. However, technological barriers that exist in realizing these options must be solved so as to overcome costs of large-scale production efficiently. Interestingly, this field opens a new forum for research.

\section{Physical and chemical conditioning as signaling factors}

Culture conditioning is extremely crucial in IMA as the conditioning source can modulate the cells. Conditioning can be categorized into two types: physical and chemical. These stimuli include electrical, mechanical, topographic, flow, co-culturing with other types of cells, and growth factors. A tissue in its $3 \mathrm{D}$ space is dependent on all aforementioned factors at any given time. Combination of soluble or tethered signaling molecules that are spatially and temporally controlled renders successful physiological establishment $[41,44,55]$. This provides evidence that the extracellular matrix (ECM) controls cell fate. The ECM environment has its own mechanical properties; these properties are sensed by cells and direct SCs to fulfill proliferation, differentiation, and maturation [46]. These mechanical properties transfer via ECM-integrin attachment [56]. Reportedly, electromechanical stimulation of cells aligned on a polymer enhanced myotube maturation as compared to non-stimulated differentiated cells [57]. Another such signal is the elasticity of cell-adhering substrates, wherein adhering substrates that can mimic in vivo environment (approximately in the range of 8-12 kilopascal; $\mathrm{KPa}$ ) exhibit higher regeneration potential than the common Petri dishes with stiffness strength equivalent to $\sim 10^{6} \mathrm{kPa}[49,58,59]$. The required elasticity should be equivalent to the tissue material measured in terms of the transcellular contractile force exerted by adhesion complexes and actin-myosin cytoskeletons [60,61]. Thus, assessing the required stiffness for stemness and differentiating SC will pave innovative approaches. Further, if other similar factors are considered and IMA requirements are optimized successfully, it is possible that media 
conditioning in the absence of serum but presence of only the basic supplement may be sufficient for successful IMA.

Apart from the above-mentioned factors, any given tissue growing above the size of 1 to $1.5 \mathrm{~mm}$ is difficult to be grown due to the limitation of nutrition and oxygen diffusion, leading to nutrition scarcity and hypoxic conditions, and ultimately, necrosis. The tissue requires angiogenesis plexus or intercalated vasculature to gain access to nutrition, oxygen, or any mitogens. One such model was engineered with a sponge-like biopolymer scaffold and co-cultured with myoblasts, fibroblasts, and endothelial cells. Accordingly, this "prevascularization" technique helped in angiogenesis, and as a result, proper perfusion of the nutrients was observed [62].

\section{CONCLUSION}

Cell-cultured meat can be an essential product that has the potential to meet our future food demands. IMA aids in animal welfare, reduction in EIDs, sustainable utilization of land and other available resources, and exhibits environmental benefits. Present focus of research should be the development of alternatives for media composition (for example, serum-free media), complete in vitro maturation of the cells, controlled SC cultivation, development of 3D matrix and microcarriers, appropriate selection of physical and chemical signals for specific cell types and regulation of cell proliferation, differentiation, and maturation, which is not only compatible with physiochemical properties but also edible [41,55,63]. Past and ongoing pandemics along with the increasing global demands for meat compels us to realize the emergent need for developing alternatives for livestock. These technology-based alternatives will ameliorate economic and food crises, human loss and suffering, and emergence of new infectious agents, thereby promising a better and safer future.

\section{REFERENCES}

1. Wolfe ND, Dunavan CP, Diamond J. Origins of major human infectious diseases. Nature. 2007;447:279-83. https://doi.org/10.1038/nature05775

2. Chen N, Zhou M, Dong X, Qu J, Gong F, Han Y, et al. Epidemiological and clinical characteristics of 99 cases of 2019 novel coronavirus pneumonia in Wuhan, China: a descriptive study. Lancet. 2020;395:507-13. https://doi.org/10.1016/S0140-6736(20)30211-7

3. Xu B, Gutierrez B, Mekaru S, Sewalk K, Goodwin L, Loskill A, et al. Epidemiological data from the COVID-19 outbreak, real-time case information. Sci Data. 2020;7:106. https://doi. org/10.1038/s41597-020-0448-0

4. Andersen KG, Rambaut A, Lipkin WI, Holmes EC, Garry RF. The proximal origin of SARSCoV-2. Nat Med. 2020;26:450-2.

5. Wu JT, Leung K, Leung GM. Nowcasting and forecasting the potential domestic and international spread of the 2019-nCoV outbreak originating in Wuhan, China: a modelling study. Lancet. 2020;395:689-97. https://doi.org/10.1016/S0140-6736(20)30260-9

6. Jones BA, Grace D, Kock R, Alonso S, Rushton J, Said MY, et al. Zoonosis emergence linked to agricultural intensification and environmental change. Proc Natl Acad Sci. 2013;110:8399404. https://doi.org/10.1073/pnas.1208059110

7. Fieldhouse JK, Wang X, Mallinson KA, Tsao RW, Gray GC. A systematic review of evidence that enteroviruses may be zoonotic. Emerg Microbes Infect. 2018;7:164. https://doi. org/10.1038/s41426-018-0159-1

8. Allen T, Murray KA, Zambrana-Torrelio C, Morse SS, Rondinini C, Di Marco M, et al. Glob- 
al hotspots and correlates of emerging zoonotic diseases. Nat Commun. 2017;8:1124. https:// doi.org/10.1038/s41467-017-00923-8

9. Jones KE, Patel NG, Levy MA, Storeygard A, Balk D, Gittleman JL, et al. Global trends in emerging infectious diseases. Nature. 2008;451:990-3. https://doi.org/10.1038/nature06536

10. Tona GO. Current and future improvements in livestock nutrition and feed resources. Anim Husb Nutr. 2018:147-69. https://doi.org/10.5772/intechopen.73088

11. FAO [Food and Agriculture Organization of the United Nations]. Impact of animal nutrition on animal welfare. Rome: FAO; 2012.

12. Lee HJ, Cho SH, Shin D, Kang HS. Prevalence of antibiotic residues and antibiotic resistance in isolates of chicken meat in Korea. Korean J Food Sci Anim Resour. 2018;38:1055-63. https://doi.org/10.5851/kosfa.2018.e39

13. Rana MS, Lee SY, Kang HJ, Hur SJ. Reducing veterinary drug residues in animal products: a review. Food Sci Anim Resour. 2019;39:687-703. https://doi.org/10.5851/kosfa.2019.e65

14. Kariyawasam KMGMM, Yang SJ, Lee NK, Paik HD. Probiotic properties of lactobacillus brevis KU200019 and synergistic activity with fructooligosaccharides in antagonistic activity against foodborne pathogens. Food Sci Anim Resour. 2020;40:297-310. https://doi. org/10.5851/kosfa.2020.e15

15. Tilman D, Clark M. Global diets link environmental sustainability and human health. Nature. 2014;515:518-22. https://doi.org/10.1038/nature13959

16. Webb P, Stordalen GA, Singh S, Wijesinha-Bettoni R, Shetty P, Lartey A. Hunger and malnutrition in the 21st century. BMJ.2018;361:k2238. https://doi.org/10.1136/bmj.k2238

17. Gerland P, Raftery AE, Ševcíková H, Li N, Gu D, Spoorenberg T, et al. World population stabilization unlikely this century. Science. 2014;346:234-7. https://doi.org/10.1126/science. 1257469

18. Ingram J. Perspective: look beyond production. Nature. 2017;544:S17. https://doi.org/10.1038/ $544 \mathrm{~S} 17 \mathrm{a}$

19. Eriksen TH, Bal E, Salemink O. A world of insecurity: anthropological perspectives on human security. London: Pluto Press; 2017.

20. Heffernan O. Sustainability: a meaty issue. Nature. 2017;544:S18-20. https://doi.org/10.1038/ $544 \mathrm{~S} 18 \mathrm{a}$

21. King A. Technology: the future of agriculture. Nature. 2017;544:S21-3. https://doi.org/ 10.1038/544S21a

22. Brack AS, Rando TA. Tissue-specific stem cells: lessons from the skeletal muscle satellite cell. Cell Stem Cell. 2012;10:504-14. https://doi.org/10.1016/j.stem.2012.04.001

23. Choi KH, Yoon JW, Kim M, Jeong J, Ryu M, Park S, et al. Optimization of culture conditions for maintaining pig muscle stem cells in vitro. Food Sci Anim Resour. 2020;40:659-67. https:// doi.org/10.5851/kosfa.2020.e39

24. Fox JL. Test tube meat on the menu? Nat Biotechnol. 2009;27:873. https://doi.org/10.1038/ nbt1009-873

25. Dance A. Engineering the animal out of animal products. Nat Biotechnol 2017;35:704-7. https://doi.org/10.1038/nbt.3933

26. Choudhury D, Tseng TW, Swartz E. The business of cultured meat. Trends Biotechnol. 2020;38:573-7. https://doi.org/10.1016/j.tibtech.2020.02.012

27. Greene JL, Angadjivand S. Regulation of cell-cultured meat. Washington, DC: Congressional Research Service; 2018.

28. Merten-Lentz K. In vitro meat: regulatory issues in the US and the EU [Internet]. 2018 [cited 2021 Jan 1]. https://tomorrowsfoodandfeed.khlaw.com/2018/12/vitro-meat-regulatory-is- 
sues-us-eu/

29. Murphy J. FDA Public Meeting for Horizontal Approaches to Food Standards of Identity Modernization, Transcript. 2019 [cited 2021 Jan1]. https://www.fda.gov/media/131428

30. Fasano J, Michael M. Formal Agreement Between the U. S. Department of Health and Human Services Food and Drug Administration and U. S. Department of Agriculture Office of Food Safety [Internet]. 2019 [cited 2021 Jan 2]. https://www.fsis.usda.gov/formalagreement

31. Rorheim A, Mannino A, Baumann T, Caviola L. Cultured meat: a pragmatic solution to the problems posed by industrial animal farming. Basel: Policy Pap by Sentience Politics; 2016.

32. Mauro A. Satellite cell of skeletal muscle fibers. J Cell Biol. 1961;9:493-5. https://doi. org/10.1083/jcb.9.2.493

33. Bentzinger CF, Wang YX, Von Maltzahn J, Soleimani VD, Yin H, Rudnicki MA. Fibronectin regulates Wnt7a signaling and satellite cell expansion. Cell Stem Cell. 2013;12:75-87. https:// doi.org/10.1016/j.stem.2012.09.015

34. Collins CA, Olsen I, Zammit PS, Heslop L, Petrie A, Partridge TA, et al. Stem cell function, self-renewal, and behavioral heterogeneity of cells from the adult muscle satellite cell niche. Cell. 2005;122:289-301. https://doi.org/10.1016/j.cell.2005.05.010

35. Ding S, Wang F, Liu Y, Li S, Zhou G, Hu P. Characterization and isolation of highly purified porcine satellite cells. Cell Death Discov. 2017;3:1-11. https://doi.org/10.1038/cddiscovery.2017.3

36. Tierney MT, Sacco A. Satellite cell heterogeneity in skeletal muscle homeostasis. Trends Cell Biol. 2016;26:434-44. https://doi.org/10.1016/j.tcb.2016.02.004

37. Cottle BJ, Lewis FC, Shone V, Ellison-Hughes GM. Skeletal muscle-derived interstitial progenitor cells (PICs) display stem cell properties, being clonogenic, self-renewing, and multi-potent in vitro and in vivo. Stem Cell Res Ther. 2017;8:1-16. https://doi.org/10.1186/s13287017-0612-4

38. Pannérec A, Formicola L, Besson V, Marazzi G, Sassoon DA. Defining skeletal muscle resident progenitors and their cell fate potentials. Development. 2013;140:2879-91. https://doi. org/10.1242/dev.089326

39. Issara U, Park S, Lee S, Lee J, Park S. Health functionality of dietary oleogel in rats fed highfat diet: a possibility for fat replacement in foods. J Funct Foods. 2020;70:103979. https://doi. org/10.1016/j.jff.2020.103979

40. Issara U, Park S, Park S. Determination of fat accumulation reduction by edible fatty acids and natural waxes in vitro. Food Sci Anim Resour. 2019;39:430-45. https://doi.org/10.5851/kofa. 2019.e38

41. Discher DE, Mooney DJ, Zandstra PW. Growth factors, matrices, and forces combine and control stem cells. Science. 2009;324:1673-7. https://doi.org/10.1126/science.1171643

42. Bentzinger CF, Wang YX, Rudnicki MA. Building muscle: molecular regulation of myogenesis. Cold Spring Harb Perspect Biol. 2012;4:a008342. https://doi.org/10.1101/cshperspect. a008342

43. Urciuolo A, Quarta M, Morbidoni V, Gattazzo F, Molon S, Grumati P, et al. Collagen VI regulates satellite cell self-renewal and muscle regeneration. Nat Commun. 2013;4:1964. https:// doi.org/10.1038/ncomms2964

44. Maleiner B, Tomasch J, Heher P, Spadiut O, Rünzler D, Fuchs C. The importance of biophysical and biochemical stimuli in dynamic skeletal muscle models. Front Physiol. 2018;9:1130. https://doi.org/10.3389/fphys.2018.01130

45. Verbruggen S, Luining D, Van Essen A, Post MJ. Bovine myoblast cell production in a microcarriers-based system. Cytotechnology. 2018;70:503-12. https://doi.org/10.1007/s10616-017- 
0101-8

46. Engler AJ, Sen S, Sweeney HL, Discher DE. Matrix elasticity directs stem cell lineage specification. Cell. 2006;126:677-89. https://doi.org/10.1016/j.cell.2006.06.044

47. Lewis WH, Lewis MR. Behavior of cross striated muscle in tissue cultures. Am J Anat. 1917;22:169-94. https://doi.org/10.1002/aja.1000220202

48. Scharner J, Zammit PS. The muscle satellite cell at 50: the formative years. Skelet Muscle. 2011;1:28. https://doi.org/10.1186/2044-5040-1-28

49. Dingal PCDP, Discher DE. Combining insoluble and soluble factors to steer stem cell fate. Nat Mater. 2014;13:532-7. https://doi.org/10.1038/nmat3997

50. Bentzinger CF, Von Maltzahn J, Rudnicki MA. Extrinsic regulation of satellite cell specification. Stem Cell Res Ther. 2010;1:27. https://doi.org/10.1186/scrt27

51. Ryall JG, Dell'Orso S, Derfoul A, Juan A, Zare H, Feng X, et al. The NAD+-dependent SIRT1 deacetylase translates a metabolic switch into regulatory epigenetics in skeletal muscle stem cells. Cell Stem Cell. 2015;16:171-83. https://doi.org/10.1016/j.stem.2014.12.004

52. Kuang S, Gillespie MA, Rudnicki MA. Niche regulation of muscle satellite cell self-renewal and differentiation. Cell Stem Cell. 2008;2:22-31. https://doi.org/10.1016/j.stem.2007.12.012

53. Gonçalves TJM, Boutillon F, Lefebvre S, Goffin V, Iwatsubo T, Wakabayashi T, et al. Collagen $\mathrm{XXV}$ promotes myoblast fusion during myogenic differentiation and muscle formation. Sci Rep. 2019;9:5878. https://doi.org/10.1038/s41598-019-42296-6

54. Wilschut KJ, Van Tol HTA, Arkesteijn GJA, Haagsman HP, Roelen BAJ. Alpha 6 integrin is important for myogenic stem cell differentiation. Stem Cell Res. 2011;7:112-23. https://doi. org/10.1016/j.scr.2011.05.001

55. Lutolf MP, Gilbert PM, Blau HM. Designing materials to direct stem-cell fate. Nature. 2009;462:433-41. https://doi.org/10.1038/nature08602

56. Heisenberg CP, Bellaïche Y. Forces in tissue morphogenesis and patterning. Cell. 2013;153:948-62.https://doi.org/10.1016/j.cell.2013.05.008

57. Liao IC, Liu JB, Bursac N, Leong KW. Effect of electromechanical stimulation on the maturation of myotubes on aligned electrospun fibers. Cell Mol Bioeng. 2008;1:133-45. https://doi. org/10.1007/s12195-008-0021-y

58. Gilbert PM, Havenstrite KL, Magnusson KEG, Sacco A, Leonardi NA, Kraft P, et al. Substrate elasticity regulates skeletal muscle stem cell self-renewal in culture. Science. 2010;329:1078-81. https://doi.org/10.1126/science.1191035

59. Eyckmans J, Chen CS. Stem cell differentiation: sticky mechanical memory. Nat Mater. 2014;13:542-3. https://doi.org/10.1038/nmat3989

60. Discher DE, Janmey P, Wang YL. Tissue cells feel and respond to the stiffness of their substrate. Science. 2005;10:1139-43. https://doi.org/10.1126/science.1116995

61. Pollard TD, Cooper JA. Actin, a central player in cell shape and movement. Science. 2009;326:1208-12. https://doi.org/10.1126/science.1175862

62. Levenberg S, Rouwkema J, Macdonald M, Garfein ES, Kohane DS, Darland DC, et al. Engineering vascularized skeletal muscle tissue. Nat Biotechnol. 2005;23:879-84. https://doi. org/10.1038/nbt1109

63. Thorrez L, Vandenburgh H. Challenges in the quest for 'clean meat.' Nat Biotechnol. 2019;37:215-6. https://doi.org/10.1038/s41587-019-0043-0

64. Roess A, Carruth L, Mann M, Kabbash I, Melaku S, Atia M, et al. Livestock movement and emerging zoonotic disease outbreaks: applying ecological, network, and sociocultural theories to assess the risk of middle East respiratory syndrome from camel trade in Ethiopia and Egypt. Lancet Glob. 2015;3:S26. http://dx.doi.org/10.1016/S2214-109X(15)70145-2 